IZA DP No. 7497

Financial Liberalization and Remittances:

Recent Longitudinal Evidence

James T. Bang

Aniruddha Mitra

Phanindra V. Wunnava

July 2013 


\title{
Financial Liberalization and Remittances: Recent Longitudinal Evidence
}

\author{
James T. Bang \\ St. Ambrose University \\ Aniruddha Mitra \\ Bard College \\ Phanindra V. Wunnava \\ Middlebury College \\ and IZA \\ Discussion Paper No. 7497 \\ July 2013 \\ IZA \\ P.O. Box 7240 \\ 53072 Bonn \\ Germany \\ Phone: +49-228-3894-0 \\ Fax: +49-228-3894-180 \\ E-mail: iza@iza.org
}

Any opinions expressed here are those of the author(s) and not those of IZA. Research published in this series may include views on policy, but the institute itself takes no institutional policy positions. The IZA research network is committed to the IZA Guiding Principles of Research Integrity.

The Institute for the Study of Labor (IZA) in Bonn is a local and virtual international research center and a place of communication between science, politics and business. IZA is an independent nonprofit organization supported by Deutsche Post Foundation. The center is associated with the University of Bonn and offers a stimulating research environment through its international network, workshops and conferences, data service, project support, research visits and doctoral program. IZA engages in (i) original and internationally competitive research in all fields of labor economics, (ii) development of policy concepts, and (iii) dissemination of research results and concepts to the interested public.

IZA Discussion Papers often represent preliminary work and are circulated to encourage discussion. Citation of such a paper should account for its provisional character. A revised version may be available directly from the author. 


\section{ABSTRACT \\ Financial Liberalization and Remittances: Recent Longitudinal Evidence*}

This paper investigates the impact of financial liberalization on remittances to 84 countries over five-year intervals from 1990-2005 based on the difference-GMM method of Arellano and Bond (1991). We find that various dimensions of financial reform impact remittances differently. Increased economic freedom in the financial sector, captured by absence of direct government control over the allocation of credit, has a positive and immediate impact. Improved robustness of financial markets, captured by the effective and apolitical regulations and other policies that enhance financial markets, has a negative, lagged effect. The net combined impact of these effects suggests that the long-run effect of an across-the-board reform on remittances is slightly negative. Our results suggest that countries using liberalization to cope with external imbalances will find that granting greater financial freedom will help by attracting higher levels of remittances. However, countries using liberalization to reduce their exposure to external risks will find that policies that enhance the robustness of domestic financial markets to be more effective.

JEL Classification: F22, O15, P48

Keywords: remittances, financial liberalization, property rights

Corresponding author:

Phanindra V. Wunnava

Department of Economics

Middlebury College

Warner Hall 502F

Middlebury, VT 05753

USA

E-mail: Phani.Wunnava@middlebury.edu

\footnotetext{
A version of this paper was presented at the $88^{\text {th }}$ Annual Meetings of the Western Economic Association International [July 2013, Seattle, WA]. We would like to thank Artatrana Ratha and the other participants in our session for their helpful comments.
} 


\section{Introduction}

Financial development has increasingly come to be acknowledged as a key determinant of the volume of formal remittances received by a country (Freund and Spatafora, 2008; Niimi et al., 2010; Mookerjee and Roberts, 2011; Bettin et al., 2012). Yet the literature has, almost without exception, ignored the impact of financial liberalization on remittances, despite the ongoing debate on the role of liberalization in the transition to financial sector development and economic growth (Kose et al., 2009; Obstfeld, 2009; Rodrik and Subramanian, 2009).

The purpose of this inquiry is to help fill this void by investigating the impact of financial reform on formal remittance inflows to a sample of 84 countries over the period 1990-2005. This area of inquiry is important because the impacts of types of liberalization policies a country takes on the level of formal remittances it receives may have important implications for that country's balance of payments in the short run, and for the country's overall level of development over the long run.

Our results indicate that the impacts of financial liberalization depend critically on the nature of the reform. Distinguishing between reforms that reduce the level of direct government control over the allocation of credit and those that enhance the robustness of the banking sector and securities markets, we find that the initial impact of freedom-oriented reforms on remittances' share of GDP is large, positive and statistically significant. We argue that the mechanism through which this effect operates is through remittances' effect of reducing transactions costs and hence increasing the supply of remittances. The impact of robustness-building reforms is smaller and statistically insignificant. However, over the long run, financial reforms that promote robustness tend to reduce remittances by improving the functions of credit markets in helping households to better use saving and borrowing to smooth consumption and by creating sound financial markets that are more capable of managing risk. Taken together, the net long-run impact of an across-the-board reform on the equilibrium level of remittances as a percentage of GDP, is slightly negative.

The next section briefly summarizes the literatures on financial liberalization and remittances and lays the conceptual foundations for our hypotheses. Then, in Section III, we briefly describe our data and estimation strategy. Section IV presents our preliminary results using a unidimensional composite measure of financial reform from Abiad et al. (2010). Section V discusses the multidimensional aspects of financial liberalization and we discuss our main 'augmented' results that take this multidimensionality into account in Section VI. Section VII discusses the policy implications of our results and concludes.

\section{Conceptual Foundations}

The fact that financial reform may have conflicting impacts on remittances underscores the need for an empirical analysis such as ours. ${ }^{1}$ Further, financial reform's relationship to individual motives to remit is also theoretically ambiguous.

To appreciate the ambiguity of this relationship, consider the insurance motive. Given sound institutions, financial liberalization reduces the cost of acquiring information and hence increases access to credit for the poor (Beck et al., 2007). Also, by opening international capital markets to diversify risk, liberalization also reduces volatility (Bekaert et al., 2006; Buch and Yener, 2010)

\footnotetext{
${ }^{1}$ The main reasons for remitting include pure altruism, coinsurance, and pure self-interest. See Rapoport and Docquier (2006) on the various incentives to remit.
} 
Moreover, liberalization stimulates economic growth, either by increasing investment and the efficiency of capital allocation (Beck et al., 2000; Bekaert et al., 2005; 2011; Henry, 2007) or indirectly via long term collateral benefits in the form of more disciplined macroeconomic policies; efficiency gains via exposure to international competition; financial development; and improved governance (Kose et al., 2009). The improved rate of growth, along with expanded access to credit, should reduce poverty and improve income distribution (Clarke et al., 2006; Beck et al., 2007), thereby reducing the political risk and, in turn, further augmenting growth.

By simultaneously reducing the level of systemic risk and improving market-based means of coping with it, financial liberalization should therefore lead to reduced reliance on remittances for insurance. At the same time, the investment motive for remitting implies that financial reform is likely to increase remittances for precisely the reasons stated above. ${ }^{2}$ Since the literature is equivocal on the relative magnitudes of various incentives to remit, the net impact of financial liberalization on remittance receipts remains ambiguous.

The ambiguity is compounded by the fact that evidence on the economic impact of financial liberalization remains inconclusive at best (Obstfeld, 2009), calling the individual impacts on the insurance and investment motives into question. In fact, there is compelling evidence that financial liberalization increases macroeconomic volatility (Kose et al., 2003; Levchenko et al., 2009) and leads to a greater risk of financial crises (Demirgüç-Kunt and Detragiache, 1998; Kaminsky and Reinhart, 1999; Reinhart and Rogoff, 2008). Further, robust evidence of the hypothesized impact of financial integration on growth remains elusive (Eichengreen, 2001; Obstfeld, 2009; Rodrik and Subramanian, 2009). Finally, there has been reason to believe that liberalization has worsened the distribution of income in societies with weak institutions (Ang, 2010). ${ }^{3}$ As such, it is conceivable that the insurance and investment effects may, have opposite signs to what has been conventionally proposed.

\section{Methodology}

To measure the impact of financial liberalization on remittance receipts, we propose the following model:

$$
(\text { Remittances } / \mathrm{GDP})_{i t}=\alpha+\rho\left(\text { Remittancs } / \mathrm{GDP}_{i, t-1}+\beta X_{i t}+\gamma Z_{i t}+\varepsilon_{i t},\right.
$$

where the dependent variable is the volume of remittances received by country $i$ in year $t$ measured as a percentage of GDP. Data is taken as five-year non-overlapping averages over the period 1990-2005, yielding an unbalanced sample of 278 observations covering 84 countries at various stages of development with up to four time periods per country.

As explanatory variables, we first include (i) the lagged value of remittances to account for the possible dynamic effects of shocks in any given period on the future values of remittance flows. Next, the vector $X_{i t}$ contains recipient-country characteristics commonly used to predict aggregate

\footnotetext{
${ }^{2}$ It is not a priori clear that international capital flows, of which remittances are a part, respond to productivity gains from financial integration. In fact, recent evidence reveals that international capital has flowed predominantly to low productivity economies, a phenomenon that has been termed the allocation puzzle (Gourinchas and Jeanne, 2007).

${ }^{3}$ The impact of financial integration on the level of inequality is further confounded by the fact that remittance income may itself act as a source of inequality (Hobbs and Jameson, 2012), though this has been disputed in the literature (Acosta et al., 2008).
} 
remittance inflows taken from various sources. The first group of variables we include in $X_{i t}$ are PPPadjusted economic indicators from the Penn World Tables, including: (ii) the lagged value log of GDP per capita (constant PPP \$); (iii) government expenditure as a percentage of GDP and its lag; and (iv) the PPP inflation rate of consumption and its lag. Next, we include (v) the total emigration rate from Defoort (2006) to account for the size of the diaspora. Also, from the Polity IV Project and the Center for Systematic Peace we include (vi) the Polity2 democracy-autocracy index to account for the state of political institutions in the emigrants' home country. ${ }^{4}$

The vector $Z_{i t}$ contains measures of financial liberalization of interest to our analysis. Our specification for the preliminary results we discuss in the next section includes (vii) a composite index of liberalization obtained from Abiad et al. (2010), who aggregate information from various dimensions of financial policy to capture the degrees to which the government is able to restrain itself from the temptation to interfere in financial markets to extract rents; promote and support robust domestic credit markets that are open to competition both domestically and internationally; and the extent to which what sound regulations are in place are transparent and are enforced apolitically. We present summary statistics for all variables in Table 1 along with a list of countries.

Finally, estimating equation (1) confronts us with a number of methodological concerns: first, GDP per capita may be endogenous and, as noted previously, may depend on the level of financial integration. Second, remittances (and other variables in our model) may be serially autocorrelated. Third, unobserved heterogeneity between countries in our panel may account for some of the observed impact of financial liberalization. To correct these issues, we use the difference-GMM method proposed by Arellano and Bond (1991).

\section{Preliminary Results}

We start our investigation by reporting the impact of the composite Abiad et al. (2010) index on the volume of remittance receipts. Column 1 in Table 2 reveals that a one standard deviation improvement in this index increases the percentage of GDP received as remittances by about 0.265 percentage points ${ }^{5}$ and the effect is significant at the $10 \%$ level. We also see that remittances are strongly and positively influenced by the emigration rate and the level of income per capita, each factoring significantly at the $1 \%$ level. Democracy and lagged values of government expenditures factor in negatively and significantly, at the $1 \%$ and $10 \%$ level, respectively.

\footnotetext{
${ }^{4}$ Given the large volume of research investigating the impact of exchange rates on remittances, we have also estimated our model with measures of the official exchange rate and exchange rate spread as robustness checks. However, there is disagreement in the literature as to the impact of exchange rates on remittances as well as the direction of the relationship (see Faini, 1994; Yang, 2008; Acosta et al., 2009 for example). Neither measure of exchange rates factors into our model with statistical significance. Also, including these measures does not substantially impact the nature of our findings. We choose to report the results from our specifications that exclude exchange rates in order to keep our model more parsimonious and less prone to having an invalid instrument structure in our GMM estimation. Complicating matters further, the International Capital Controls variable of the financial reforms database contains in it a measure of dual exchange rate regimes, which would tend to exhibit collinearity with any exchange rate variable we might choose to include.
}

${ }^{5}$ This value is obtained by multiplying the coefficient of 0.0534 by the standard deviation of the financial reform composite of 4.964 . 
Notice as well that, in contrast to other studies (Ratha, 2003, for example) we do not observe a high degree of persistence in the levels of remittances in our sample. This might be because of the fact that the structure of a country's financial institutions is what is driving the high levels of persistence observed in these previous studies. However, since we have modeled financial liberalization to only have a contemporaneous effect on remittances, another implication of this finding is that the impact of a once-and-for-all financial reform leads to an almost immediate convergence to the new long-run level of remittances.

We demonstrate this rapid convergence by calculating the impulse response functions for a permanent reform at time $t=0$ equal to a one standard deviation change in the level of the financial reform composite variable of Abiad et al. (2010). We illustrate this response function for the year of the shock plus the five years following the shock in the solid line in Figure 1. The impact of a reform in period zero is shown by the 0.265 percentage point jump in remittances at time zero, which is the same as the effect described above. This increase is then followed by a slight reduction in the second period, with nearly full convergence to the new equilibrium (to the fifth decimal place) being achieved by the third period after the reform. ${ }^{6}$ Given the supposed long-run effects of financial liberalization posited in the literature, we find this to be implausible.

Therefore, as a second step, in addition to a contemporaneous impact of financial liberalization, we consider lagged values of the financial reform in our specification. We report the results of this extension in column (2) of Table 2. From these results, we see a much more interesting pattern: While financial reform positively and significantly impacts liberalization in the concurrent period of the reform, its corresponding lagged effect is negative, statistically significant at the $10 \%$ level, and nearly equal in magnitude to the contemporaneous effect. Hence, as illustrated by the dashed line in Figure 1, a one standard deviation improvement in a government's policies towards financial markets will increase remittances by about 0.36 percentage points in the period of the reform. However, remittances will also subside by an approximately equal amount in the period immediately following, ${ }^{7}$ resulting in only a tiny net effect on remittances once the country converges to the long-run equilibrium by about the fourth period after the shock. ${ }^{8}$

${ }^{6}$ The additional change in the period after reform is equal to: $d\left(\frac{\text { Remittances }}{G D P}\right)_{i, 1}=\rho \gamma d(\text { Reform })_{i, 0}$. Plugging in the estimated coefficients, and assuming a one standard deviation of the Financial Reform Index (4.964) for d(Reform $)_{i, 0}$, this becomes: $d\left(\frac{\text { Remittances }}{G D P}\right)_{t}=-0.0545(0.0534)(4.964)=-0.0144$. The cumulative effect, then, relative to the previous equilibrium is equal to the contemporaneous effect $(0.265)$ plus the lagged effect in the next period $(-0.0144)$, which is 0.2506

${ }^{7}$ The change in the next period is: $d\left(\frac{\text { Remittances }}{G D P}\right)_{i, 1}=\rho \gamma d\left(\right.$ Reform $_{i, 0}+\gamma d\left(\right.$ Reform $\left._{i, 0}\right)$. Using the estimated values, and assuming a standard deviation change, $d\left(\frac{\text { Remittances }}{G D P}\right)_{t}=-0.0545(0.0534)(4.964)+0.0534(4.964)=-0.391$. The cumulative effect, then, relative to the previous equilibrium is equal to the contemporaneous effect ( 0.362$)$ plus the lagged effect in the next period (-0.391), which is -0.0288 . By the fourth period after reform the cumulative effect is 0.004568 ; in the fifth period, it is 0.004538 ; in the $20^{\text {th }}$ period it is 0.004540 .

\footnotetext{
${ }^{8}$ Including a lagged value for financial reform does not require us to sacrifice any observations because the time series for the financial reform database begins in 1981, whereas the lagged differences for our dependent variable needed to estimate the difference GMM model are only available beginning for the five year period ending in 1990. Ideally, we would like to be able to test for the optimal lag length in the impact of financial reform on remittances. However, given the shortness of
} 
One caveat with the above analysis is that it fails to capture the different impacts of the various types of liberalization policies on the level of remittances through their different impacts on transactions costs and household investment and wealth, respectively. The next section discusses one strategy for capturing these distinctions in the measurement of financial liberalization.

\section{Capturing Multidimensionality of Financial Institutions}

One of the problems in our analysis using the financial reform composite variable of Abiad et al. (2010) is the fact that this composite is actually the sum of eight different indicators of financial liberalization: (a) Directed credit, (b credit controls, (c) interest rate controls, (d) entry barriers, (e) banking supervision, (f) privatization, (g) international capital controls, and (h) security markets policies. Combining these variables additively into a composite index is both methodologically and conceptually inappropriate for our investigation for reasons we describe below.

Adding these variables to form a single composite measure of financial liberalization introduces the possibility that the fluctuations in financial liberalization, broadly defined, are only being captured with considerable measurement error. This is because the individual proxies of financial liberalization purport to measure different dimensions of liberalization and reform by construction. Hence, treating a one unit change in "directed credit", for example, the same as a one unit change in "banking supervision" (as the "liberalization" composite does) is at best ad hoc and at worst entirely inappropriate.

One method that is commonly used in the literature on the impacts of political institutions on economic performance to avoid subjectivity in the construction of indexes is to perform a principal component analysis (PCA) on the observed proxy variables, and interpret the first component of the analysis as institutional quality. This is the essence of what Alesina and Perotti (1996), Perotti (1996), and Keefer and Knack (1997) do in the context of investigating the influence of institutional quality on economic growth. Alternatively, following Alesina et al. (1996), one could construct a unidimensional index of institutional quality by using logit analysis.

However, as argued by Jong-A-Pin (2009) in the context of measuring the impact of political instability, financial liberalization is likely to have multiple dimensions, and it is our hypothesis that these different dimensions may have distinct impacts on the different motives for remitting. For example, certain measures of a country's financial institutions' quality may have greater impacts on remittances through their impacts on investment and development in the home region and the corresponding increase in wealth and decrease in the demand (or need) for remittances. Other measures may have greater impacts through role in reducing the transactions costs of sending remittances, and hence increasing the supply of remittances. Hence, a unidimensional index is not sufficient for our objective.

To avoid these problems, we perform an exploratory factor analysis (EFA) on the eight variables mentioned above to obtain two distinct (and relatively uncorrelated) measures of financial liberalization. This method allows us to identify combinations of variables that explain different aspects of financial institutions and can be interpreted more broadly than a single variable, yet at the same time are uncorrelated. The factors that emerge from this procedure are (continuing the

our sample $(t=4)$, including additional lagged values of financial reform would require sacrificing an entire time period of observations, which would begin to call into question the consistency of our estimated coefficients. 
enumeration of variables from Section III): (viii) the freedom of financial markets from direct government interference; and (ix) the robustness of government policies towards promoting and transparently regulating financial institutions. We briefly explain factor analysis and how we interpret the results to obtain these factors below.

Factor analysis and principal component analysis are related. However, whereas PCA aims to extract the maximum amount of variation from the variables possible into a single component, EFA seeks to capture the common sources of variation among the variables. In addition, in PCA, the components are linear combinations of the observed variables; in EFA, the observed variables are linear combinations of the constructed latent factors. These features allow us to interpret the predicted factors and attach conceptual meaning to them. PCA does not lend itself as well to such interpretation.

The results of this exercise are reported in Table 3. To understand the interpretation of the factors, note that the first factor is primarily determined by the absence of directed credit policies and high reserve requirements (0.966); and the absence of credit ceilings (0.954). Since all of the dominant variables reflect the absence of policies that curtail the freedom of privately-owned banks, we interpret the factor the freedom of the financial sector. By contrast, the second factor is dominated by the absence of international capital controls (0.729); the presence of policies that develop security markets (0.700); the independence of banking supervision (0.594); the absence of interest rate controls (0.549); the absence of barriers to entry in the banking sector (0.479); and the level of privatization in the banking sector (0.334). Since each of these facets contributes to enhancing the efficiency of the financial sector, we interpret this factor as capturing the robustness of financial markets. The third factor, which is loosely composed of by privatization (0.425), entry barriers (0.340), and banking supervision (0.305), could be said to represent the competitiveness of financial markets. However, the first two factors explain an overwhelming majority of the common variance, and the third factor also happens to be correlated with robustness. Therefore, following common practice, we do not include this factor in our main regressions we discuss in the results section, but we do explore the impact of this variable as a robustness check. ${ }^{9}$

Notice as well that all of the variables (other than directed credit and credit controls) also appear to make marginal contributions to the construction of financial freedom, but none surpasses the threshold of 0.300 in terms of the value of its factor loading. Hence, our interpretation of the second factor is conditioned on the fact that the factor loadings for this factor extract the common variance in the direction of financial robustness that is not already captured in the other factors that emerge from the analysis, namely the level of financial freedom. Therefore, the fact that privatization contributes significantly to the robustness factor is not surprising since we have already filtered out most of its common variance in the direction of financial freedom.

\section{Augmented Results with Multidimensionality of Financial Institutions}

Differentiating between the two dimensions of financial reform, column (1) of Table 4 reveals a strong positive impact of financial freedom on remittances. On average, a standard deviation improvement in the freedom factor increases the growth in ratio of remittances to GDP by a factor of 0.24 percentage points and the impact is significant at the 5\% level. By contrast, a comparable improvement in

\footnotetext{
${ }^{9}$ Results available on request
} 
financial robustness has a smaller (about 0.17 percentage point), and statistically insignificant impact. This suggests that the initial impact of a reduction in the level of direct government interference in the financial sector results in a reduction in the level of transactions costs of sending remittances and therefore boosts their supply, which is consistent with the findings of Freund and Spatafora (2008) and others. Interestingly, an increase in the transparency and efficiency of government policies that regulate the banking sector and promote foreign investment and robust securities markets do not seem to have a strong impact on transactions costs.

The solid line in Figure 2 illustrates the dynamics of the impact of the financial freedom factor on remittances. ${ }^{10}$ This function shows that the initial impact of a one standard deviation reduction in the government's control of the financial sector initially boosts remittances by the 0.24 percentage points described above. This increase remains largely intact as we project the effect forward to the new longrun equilibrium that is about 0.225 percentage points higher than it was before the reform. The impact of robustness, depicted by the solid line in Figure 3, displays a weaker (and statistically insignificant) initial impact (of about 0.17 percentage points) that settles in a long run equilibrium that is about 0.16 percentage points higher on average than the pre-reform equilibrium. Combining these effects, the solid line in Figure 4 shows the impact on remittances resulting from a permanent, across-the-board, standard deviation change in the level of financial freedom and financial robustness. This figure shows an initial increase of about 0.40 percentage points that converges to a positive long-run impact that is about 0.38 percentage points higher than the pre-reform equilibrium.

As before, we extend our analysis by considering lagged effects in our financial reform variables, which we report in column (2) of Table 4 and the dashed lines in Figures 2 and 3. These results suggest an interesting bifurcation that we could not detect when we examined the effects of the unidimensional financial reform composite variable in Section 3: Policies that reduce the level of direct government intrusion in financial markets have immediate, positive, and fairly long-lasting effects on the level of remittances; policies that enhance the government's ability to transparently regulate the banking sector and effectively support the development of robust financial markets have very little (and statistically insignificant) initial effects, but have negative, significant, and long-lasting lagged effects on the levels of remittances.

It is perhaps not too surprising that financial liberalization in general, and the absence of government interference in credit markets in particular increases the level of remittances a country receives. This result is well-documented by Freund and Spatofora (2008), who estimate the levels of informal remittances a country receives by determining the impact of reductions in transactions costs (which they measure in terms of financial liberalization and development) on the level of formal remittances. This effect would also be stronger the greater the extent to which emigrants are motivated to send remittances home out of a self-interested desire to invest.

What may be somewhat more surprising, and which bears further discussion, is the fact that financial reforms that improve financial "robustness" - the removal of international capital controls and exchange rate distortions, implementation of policies that promote securities markets, and the adoption of sound banking regulations, for example - actually have negative long-run impacts on the

${ }^{10}$ The values for the figures discussed in this section are calculated in the same way described in Section IV (see footnote $5)$. 
level of remittances. To start, it is worthwhile to note that robustness-enhancing financial reforms, though statistically insignificant, do in fact have a positive initial impact on remittances on average, presumably due to their impact on transactions costs. However, in our model, the lagged impact of robustness is negative, large in magnitude, and statistically significant at the 0.05 level. Moreover, as shown in Figure 3, the impact of robustness on the long-run equilibrium level of remittances is negative. This suggests that the impact of robustness on remittances operates through channels other than simply reducing transactions costs.

One explanation for this can be found in the motives for remitting. To the extent that emigrants are motivated to send remittances by an unspoken agreement with their families in the home region to coinsure against adverse income shocks, an increase in the availability of credit domestically can be expected to reduce the demand for remittances. This is because enhanced availability of credit domestically increases emigrants' families' ability to smooth consumption by purchasing insurance in the market, or by obtaining loans to lessen the blow of temporary shocks. Moreover, to the extent that more robust financial markets enhance household wealth, they will also be expected to reduce the amount of remittances that emigrants send out of a sense of altruism. Thus, it is not too surprising that we see a negative effect from the robustness factor after all.

One final question pertains to the potential impacts of across-the-board liberalization that both reduces government intervention and enhances policies designed to increase the robustness of financial markets. We illustrate the dynamics of the effects of this approach to liberalization in Figure 4. For the model without lagged values of financial reform, this approach leads to an initial increase in remittances equal to about 0.40 percentage points, and the impact remains relatively flat and reaching a new equilibrium at about 0.38 percentage points above the previous one. However, it is interesting to note that this effect fails to achieve statistical significance at even the 0.10 level. ${ }^{11}$ When we do include lagged effects, however, the initial impact is slightly stronger and statistically significant, ${ }^{12}$ with a jump in remittances of about 0.59 percent of GDP. However, in the first period after the reform, the negative lagged effects of robustness dominate, and remittances drop by about 0.69 percent of GDP. $^{13}$ The long run effect of the reform is to reduce remittances by about 0.10 percent of GDP. ${ }^{14}$

To check the sensitivity of our empirical results, we have also estimated the model presented in Tables 2 and 4 using a balanced panel, the results of which we report in Table A1 in the Appendix. It is important to note, however that balancing the panel in our sample leads to a considerable loss in the number of countries our sample covers from 84 to 56, and the countries that drop out are not selected

\footnotetext{
${ }^{11}$ The estimated effect for the combined effect of a one standard deviation change in both factors is about 0.4012; the estimated standard error of this linear combination is about 0.2500 , resulting in a z-statistic of about 1.60 and a p-value of about 0.109 .

${ }^{12}$ The point estimate for the linear combination is 0.5850 and the standard error is 0.2850 , yielding a test statistic of 2.04 and a p-value of 0.040 .

${ }^{13}$ This nonlinear effect is also statistically significant. The point estimate for the effect in the second period is equal to: $0.894\left(\hat{\beta}_{\text {freedom }(t-1)}\right)+0.831\left(\hat{\beta}_{\text {robustness }(t-1)}\right)+0.894\left(\hat{\beta}_{\text {remit }(t-1)}\right)\left(\hat{\beta}_{\text {freedom }(t)}\right)+0.831\left(\hat{\beta}_{\text {remit }(t-1)}\right)\left(\hat{\beta}_{\text {freedom }(t)}\right)=-0.6916$.

Since the test contains nonlinear combinations of the coefficients, a simple z-test is not valid here. However a Wald test can be performed. The value of the Wald statistic for this test is 4.13, and the Bonferroni-adjusted p-value for the test is 0.042 .

${ }^{14}$ The cumulative effect on remittances after two periods is -0.1071 , but this effect is not statistically significant.
} 
at random. In fact, not only is it the case that we lose a considerable number of non-OECD countries when we balance our panel, but many of those countries that drop out are transition countries. Since these countries are precisely the ones in which some of the most significant financial liberalizations have occurred, omitting these countries from the analysis may worsen the scope for selection bias.

In spite of this, we are encouraged that the qualitative nature of our results remains largely intact. Focusing on the model with the factor variables that includes lags (column 4), we see that a contemporaneous increase in the financial freedom variable by one standard deviation increases remittances by a statistically significant (at the 5\% level) 0.32 percent of GDP, whereas a comparable increase in the robustness factor increases remittances by about 0.02 percent of GDP, and the effect is statistically insignificant. The lagged effect of a one standard deviation improvement freedom is -0.22 percent of GDP, which is statistically significant at the $10 \%$ level, while the lagged effect of robustness is about 0.52 percent of GDP, and the effect is significant at the 0.05 level.

\section{Conclusion}

In undertaking a nuanced exploration of financial liberalization as a determinant of remittance inflows, the paper contributes to three distinct literatures: $(i)$ it contributes to the literature on macroeconomic determinants on remittances. (ii) it contributes to the literature on the economic impact of financial liberalization by identifying an indirect channel of influence that operates via remittance receipts. (iii) it sheds light on the literature that investigates the role of remittances as a substitute or complement for financial development.

Further, this paper highlights the importance of acknowledging the possibility that financial reform may be a multidimensional concept. By performing an exploratory factor analysis on eight indicators, we identify at least two distinct aspects of financial liberalization: freedom from direct government interference marked by the absence of credit controls and directed credit programs; and government support for enhanced robustness in the financial sector marked by apolitical regulation, the absence of currency manipulation and other policies that restrict international capital flows, and policies that promote securities markets.

These factors have different implications for the effects of reform on remittances. We find that financial freedom impacts remittances positively, directly and immediately, through their role in reducing the transactions costs (which may include expropriation by the government). Financial robustness, on the other hand, impact remittances negatively, indirectly and with a lag, through their role in helping households use markets to insure against income risk and providing sufficient asset security to build wealth.

The policy implications of our results are likely to vary depending on the situation a country faces. Countries using liberalization to help overcome balance of payment crisis may find that granting financial institutions greater freedom will complement other efforts to reestablish external balance by attracting higher levels of remittances. However, countries using liberalization as a strategy to become less dependent on external transfers will find that policies that enhance the robustness of domestic financial markets to be more effective.

Further work on the topic of financial liberalization might include an investigation the role of the different dimensions of financial reform on foreign investment and trade, and possibly how those types of flows in turn impact the levels of remittances a country receives. Also, as the availability of bilateral remittances increases, a natural extension of the current work would test the relative roles of financial 
institutions in the emigrants home and host countries on the levels of remittances transferred between a pair of countries. 


\section{References}

Abdih, Y., Chami, R., Dagher, J., and Montiel, P. (2012) Remittances and Institutions: Are Remittances a Curse? World Development, 40(4), 657-666.

Abiad, A., Detragiache, E. and Tressel, T. (2010), A new database of financial reforms, IMF Staff Papers, 57(2), 281-302.

Acosta, P., Calderon, F., Fajnzylber, P. and Lopez, H. (2008) What is the Impact of International Remittances on Poverty and Inequality in Latin America? World Development, 36(1), 89-114.

Acosta, P. A., Lartey, E. K., \& Mandelman, F. S. (2009) Remittances and the Dutch disease, Journal of International Economics, 79(1), 102-116.

Aggarwal, R., Demirgüç-Kunt, A., and Martinez Peria, M.S. (2011) Do Workers' Remittances Promote Financial Development? Journal of Development Economics, 96(2), 255-264.

Alesina, A., and Perotti, R. (1996) Income distribution, political instability and investment. European Economic Review 40(6), 1203-1228.

Alesina, A., Özler, S., Roubini, N., and Swagel, P. (1996) Political instability and economic growth. Journal of Economic Growth, 1(2), 189-211.

Ang, J.B. (2010) Finance and inequality: the case of India, Southern Economic Journal, 76(3), 738761.

Arellano, M., and Bond, S. (1991) Some tests of specification for panel data: Monte Carlo evidence and an application to employment equations. Review of Economic Studies, 58, 277-297.

Barajas, A., Chami, R., Fullenkamp, C., Gapen, M., and Montiel, P.J. (2009) Do Workers' Remittances Promote Economic Growth? IMF Working Paper No. 09/153, International Monetary Fund (IMF), Washington, D.C.

Beck, T., Levine, R., and Loayza, N. (2000) Finance and the sources of growth, Journal of Financial Economics, 58 (1-2), 261-300

Beck, T., Demirgüç-Kunt, A., and Levine, R. (2007) Finance, inequality, and the poor, Journal of Economic Growth, 12 (1), 27-49.

Bekaert, G., Harvey, C.R., and Lundblad, C. (2005) Does financial liberalization spur economic growth? Journal of Financial Economics, 77(1), 3 - 55.

Bekaert, G., Harvey, C.R. and Lundblad, C. (2006) Growth volatility and financial liberalization, Journal of International Money and Finance, 25(3), 370-403.

Bekaert, G., Harvey, C.R. and Lundblad, C. (2011) Financial openness and productivity, World Development, 39(1), 1-19. 
Bettin, G., Lucchetti, R. and Zazzaro, A. (2012) Financial development and remittances: Microeconometric evidence, Economics Letters, 115(2), 184-186.

Bollard, A., McKenzie, D., Morten, M. and Rapoport, H. (2011) Remittances and the brain drain revisited: The microdata show that more educated migrants remit more, World Bank Economic Review, 25(1), 132-156.

Buch, C. M. and Yener, S. (2010) Consumption volatility and financial openness, Applied Economics, 42(28), 3635-3649.

Catrinescu, N., León-Ledesma, M., Piracha, M. and Quillin, B. (2009) Remittances, Institutions, and Economic Growth, World Development, 37(1), 81-92.

Clarke, G.R.G., Xu, L.C., and Zou, H-F. (2006) Finance and Income Inequality: What Do the Data Tell Us? Southern Economic Journal, 72(3), 578-596.

Demirgüç-Kunt, A. and Detragiache, E. (1998) Financial liberalization and financial fragility, IMF Working Paper No. 98/83, International Monetary Fund (IMF), Washington, D.C.

Demirgüç-Kunt, A., Lopez Cordova, E., Martinez Peria, M.S., and Woodruff, C. (2011) Remittances and banking sector breadth and depth: Evidence from Mexico, Journal of Development Economics, 95(2), 229-241.

Eichengreen, B. (2001) Capital Account Liberalization: What Do Cross-Country Studies Tell Us? World Bank Economic Review, 15(3), 341-65.

Faini, R. (1994) Workers remittances and the real exchange rate, Journal of Population Economics, $7(2), 235-245$.

Faini, R. (2007) Remittances and the Brain Drain: Do More Skilled Migrants Remit More? World Bank Economic Review, 21(2), 177-191.

Freund, C. and Spatafora, N. (2008) Remittances, transaction costs, and informality, Journal of Development Economics, 86 (2), 356-366.

Giuliano, P. and Ruiz-Arranz, M. (2009) Remittances, financial development, and growth, Journal of Development Economics, 90 (1), 144-152.

Gourinchas, P-O. and Jeanne, O. (2007) Capital flows to developing countries: the allocation puzzle, NBER Working Paper No. 13602, National Bureau of Economic Research (NBER), Cambridge, MA.

Gupta, S., Pattillo, C. and Wagh, S. (2009) Effect of Remittances on Poverty and Financial Development in Sub-Saharan Africa, World Development, 37(1), 104-115.

Henry, P.B. (2007) Capital account liberalization: theory, evidence, and speculation, Journal of Economic Literature, 45, 883-935. 
Hobbs, A.W. and Jameson, K.P. (2012) Measuring the effect of bi-directional migration remittances on poverty and inequality in Nicaragua, Applied Economics, 44(19), 2451-2460.

Kaminsky, G.L. and Reinhart, C.M. (1999) The twin crises: the causes of banking and balance-ofpayments problems, American Economic Review, 89(3), 473-500.

Kose, M.A., Prasad, E. and Terrones, M.E. (2003) Financial integration and macroeconomic volatility, IMF Staff Papers, 50, International Monetary Fund (IMF), Washington, D.C., 119-42.

Kose, M.A., Prasad, E., Rogoff, K., and Wei, S-J. (2009) Financial globalization: a reappraisal, IMF Staff Papers, 56, 8-62.

León-Ledesma, M. and Piracha, M. (2004) International Migration and the Role of Remittances in Eastern Europe, International Migration, 42(4), 65-84.

Levchenko, A.A., Rancière, R., and Thoenig, M. (2009) Growth and Risk at the Industry Level: the Real Effects of Financial Liberalization, Journal of Development Economics, 89(2), 210-222.

Mitra, A., Bang, J.T. and Wunnava, P.V. (2013) Financial Liberalization and the Selection of Emigrants: A Cross-national Analysis, Empirical Economics (Forthcoming).

Mookerjee, R. and Roberts, J. (2011) Banking services, transaction costs and international remittance flows, Applied Economic Letters, 18 (3), 199-205.

Mundaca, G. (2009) Remittances, Financial Market Development, and Economic Growth: The Case of Latin America and the Caribbean, Review of Development Economics, 13(2), 288-303.

Niimi, Y., Özden, C. and Schiff, M. (2010) Remittances and the brain drain: skilled Migrants do remit less, Annales d'Economie et de Statistique, 97-98, 123-141.

Obstfeld, M. (2009) International finance and growth in developing countries: what have we learned? NBER Working Paper No. 14691, National Bureau of Economic Research (NBER), Cambridge, MA.

Rajan, R.G. and Zingales, L. (2003) The great reversals: the politics of financial development in the twentieth century, Journal of Financial Economics, 69(1), 5-50.

Rapoport, H. and Docquier, F. (2006) The economics of migrants' remittances, in Handbook of the Economics of Giving, Altruism and Reciprocity (Eds) S-C. Kolm and J.M. Ythier, Elsevier, Amsterdam, Vol. 2, 1135-1198.

Ratha, D. (2003) Workers' Remittances: An Important Source of External Development Finance, in Global Development Finance 2003: Striving for Stability in Development Finance, World Bank, Washington, D.C. 
Reinhart, C.M. and Rogoff, K.S. (2008) This time is different: a panoramic view of eight centuries Of financial crises, NBER Working Paper No. 13882, National Bureau of Economic Research (NBER), Cambridge, MA.

Rodrik, D. and Subramanian, A. (2009) Why Did Financial Globalization Disappoint? IMF Staff Papers, 56, 112-138.

Stiglitz, J.E. (2000) Capital market liberalization, economic growth, and instability, World Development, 28 (6), 1075-1086.

Yang, D. (2008) International Migration, Remittances and Household Investment: Evidence from Philippine Migrants' Exchange Rate Shocks, The Economic Journal, 118(528), 591-630. 
Table 1: Summary Statistics ${ }^{\mathrm{a}}$

\begin{tabular}{|c|c|c|c|c|c|c|}
\hline Variable & Description & Source & Mean & Std. Dev. & Min & Max \\
\hline Remittances $_{t}$ & \multirow{2}{*}{$\begin{array}{l}\text { Total Remittances divided by GDP } \\
\text { (x 100\%). }\end{array}$} & UN Dev. Program & 2.378 & 3.590 & 0.002 & 22.693 \\
\hline Remittances $_{t-1}$ & & UN Dev. Program & 2.041 & 3.437 & 0.002 & 22.693 \\
\hline Emigration Rate $_{t-1}$ & $\begin{array}{l}\text { Total number of emigrants as a } \\
\text { percentage of the total population. }\end{array}$ & DeFoort (2006) & 0.033 & 0.052 & 0.001 & 0.352 \\
\hline $\ln (\text { GDP per Capita })_{t-1}$ & $\begin{array}{l}\text { Natural log of PPP-equivalent GDP } \\
\text { per capita in year } 2000 \text { US\$. }\end{array}$ & Penn World Tables & 8.559 & 1.241 & 5.783 & 10.665 \\
\hline Gov. Expenditure $_{t}$ & \multirow{2}{*}{$\begin{array}{l}\text { PPP-equivalent government. } \\
\text { expenditure as a percentage of PPP- } \\
\text { equivalent GDP. }\end{array}$} & Penn World Tables & 8.959 & 3.714 & 1.772 & 21.923 \\
\hline Gov. Expenditure ${ }_{t-1}$ & & Penn World Tables & 9.227 & 3.946 & 1.669 & 24.776 \\
\hline Inflation $_{t}$ & \multirow{2}{*}{$\begin{array}{l}\text { PPP-adjusted inflation rate for } \\
\text { consumption goods. }\end{array}$} & Penn World Tables & 0.011 & 0.057 & -0.161 & 0.228 \\
\hline Inflation $_{t-1}$ & & Penn World Tables & 0.002 & 0.105 & -0.161 & 0.854 \\
\hline Polity Index & Polity 2 democracy-autocracy index & Polty IV Project & 4.697 & 6.064 & -8.600 & 10.000 \\
\hline Financial Reform $t$ & \multirow{2}{*}{$\begin{array}{l}\text { Abiad et al. (2010) index of } \\
\text { financial reform (sum of six } \\
\text { indicators) }\end{array}$} & Abiad, et al (2010) & 14.081 & 4.964 & 0 & 21 \\
\hline Financial Reform ${ }_{t-1}$ & & Abiad, et al (2010) & 11.661 & 5.796 & 0 & 21 \\
\hline Directed Credit ${ }_{t}$ & $\begin{array}{l}\text { Absence of lending requirements to } \\
\text { "priority" sectors. }\end{array}$ & Abiad, et al (2010) & 2.097 & 0.988 & 0 & 3 \\
\hline Credit Controls $t_{t}$ & $\begin{array}{l}\text { Absence of highly restrictive } \\
\text { reserve or capital requirements } \\
\text { and/or government-imposed credit } \\
\text { ceilings. }\end{array}$ & Abiad, et al (2010) & 2.160 & 0.929 & 0 & 3 \\
\hline Interest Rate Controls ${ }_{t}$ & $\begin{array}{l}\text { Absence of government-set interest } \\
\text { rates and/or interest rate "ceilings" } \\
\text { or "floors." }\end{array}$ & Abiad, et al (2010) & 2.525 & 0.886 & 0 & 3 \\
\hline Entry Barriers $_{t}$ & $\begin{array}{l}\text { Absence of restrictions on entry to } \\
\text { the banking sector, such as outright } \\
\text { entry restrictions, restrictions on } \\
\text { foreign entry, or restrictions on the } \\
\text { scope of certain banks' activities. }\end{array}$ & Abiad, et al (2010) & 2.338 & 0.954 & 0 & 3 \\
\hline Banking Supervision $_{t}$ & $\begin{array}{l}\text { Prudential banking regulations (e.g. } \\
\text { Basle capital standards); }\end{array}$ & Abiad, et al (2010) & 1.353 & 1.004 & 0 & 3 \\
\hline
\end{tabular}




\begin{tabular}{|c|c|c|c|c|c|c|}
\hline & $\begin{array}{l}\text { supervisory agencies independent } \\
\text { of the executive branch; and on- } \\
\text { and off-site enforcement. }\end{array}$ & & & & & \\
\hline Privatization $_{t}$ & $\begin{array}{l}\text { The extent to which the banking } \\
\text { sector is privately-held (as opposed } \\
\text { to state-owned). }\end{array}$ & Abiad, et al (2010) & 1.590 & 1.167 & 0 & 3 \\
\hline $\begin{array}{l}\text { International Capital } \\
\text { Controls }_{t}\end{array}$ & $\begin{array}{l}\text { The absence of government } \\
\text { restrictions on the inflow or outflow } \\
\text { of foreign capital, or multiple } \\
\text { exchange rate regimes. }\end{array}$ & Abiad, et al (2010) & 2.122 & 0.987 & 0 & 3 \\
\hline $\begin{array}{l}\text { Security Markets } \\
\text { Policies }_{t}\end{array}$ & $\begin{array}{l}\text { Policies to develop securities } \\
\text { markets, e.g. T-bill auctions; } \\
\text { multiple-term gov. bonds; corp. } \\
\text { bonds, equities, and derivatives } \\
\text { markets; absence of restrictions on } \\
\text { foreign participation. }\end{array}$ & Abiad, et al (2010) & 1.993 & 0.961 & 0 & 3 \\
\hline Freedom Factor ${ }_{t}$ & \multirow{2}{*}{$\begin{array}{l}\text { Directed credit }(0.966) \text { and credit } \\
\text { controls }(0.954) .\end{array}$} & Mitra, et al. (2013) & 0.410 & 0.894 & -1.839 & 1.838 \\
\hline Freedom Factor ${ }_{t-1}$ & & Mitra, et al. (2013) & 0.197 & 0.934 & -1.771 & 1.838 \\
\hline Robustness Factor $_{t}$ & \multirow{2}{*}{$\begin{array}{l}\text { International capital controls } \\
(0.729) \text {; securities market policies } \\
(0.700) \text {; banking supervision } \\
(0.594) \text {; int. rate controls }(0.549) \text {. }\end{array}$} & Mitra, et al. (2013) & 0.400 & 0.831 & -1.927 & 2.241 \\
\hline Robustness Factor ${ }_{t-1}$ & & Mitra, et al. (2013) & 0.112 & 0.853 & -1.927 & 2.241 \\
\hline Number of Observations & & & 278 & & & \\
\hline Number of Countries & & & 84 & & & \\
\hline
\end{tabular}

${ }^{a}$ Countries: Albania, Algeria, Argentina, Australia, Austria, Azerbaijan, Bangladesh, Belarus, Belgium, Bolivia, Brazil, Bulgaria, Burkina Faso, Cameroon, Chile, China, Colombia, Costa Rica, Cote d'Ivoire, Czech Republic, Denmark, Dominican Republic, Ecuador, Egypt, El Salvador, Estonia, Ethiopia, Finland, France, Georgia, Germany, Ghana, Greece, Guatemala, Hungary, India, Indonesia, Ireland, Israel, Italy, Jamaica, Japan, Jordan, Kazakhstan, Kenya, Korea, Republic of, Kyrgyzstan, Latvia, Lithuania, Madagascar, Malaysia, Mexico, Morocco, Mozambique, Nepal, Netherlands, New Zealand, Nicaragua, Nigeria, Norway, Pakistan, Paraguay, Peru, Philippines, Poland, Portugal, Russia, Senegal, South Africa, Spain, Sri Lanka, Sweden, Switzerland, Tanzania, Thailand, Tunisia, Turkey, Uganda, Ukraine, United Kingdom, United States, Venezuela, Vietnam, Zimbabwe. 
Table 2: Preliminary Difference GMM Estimation Results (Dependent Variable: Remittances as a percentage of GDP)

\begin{tabular}{|c|c|c|}
\hline & $(1)$ & $(2)$ \\
\hline Remittances $_{t-1}(\%$ of GDP) & $\begin{array}{l}-0.0545 \\
(0.153)\end{array}$ & $\begin{array}{l}-0.0932 \\
(0.158)\end{array}$ \\
\hline Emigration Rate $_{t-1}$ (\% of Pop.) & $\begin{array}{c}58.50 * * * \\
(11.12)\end{array}$ & $\begin{array}{c}63.30 * * * \\
(11.72)\end{array}$ \\
\hline $\ln (\text { GDP per Capita })_{t-1}(\$ U S 2000)$ & $\begin{array}{c}3.343 * * * \\
(1.154)\end{array}$ & $\begin{array}{c}5.257 * * * \\
(1.604)\end{array}$ \\
\hline Gov. Expenditure $_{t}(\%$ of GDP $)$ & $\begin{array}{l}-0.0185 \\
(0.0917)\end{array}$ & $\begin{array}{l}-0.0200 \\
(0.0966)\end{array}$ \\
\hline Gov. Expenditure $_{t-1}(\%$ of GDP) & $\begin{array}{l}-0.141 * \\
(0.0775)\end{array}$ & $\begin{array}{l}-0.161 * * \\
(0.0812)\end{array}$ \\
\hline Inflation $_{t}$ (Consumption) & $\begin{array}{c}0.159 \\
(1.372)\end{array}$ & $\begin{array}{l}-0.189 \\
(1.460)\end{array}$ \\
\hline Inflation $_{t-1}$ (Consumption) & $\begin{array}{l}-0.660 \\
(0.828)\end{array}$ & $\begin{array}{l}-0.879 \\
(0.880)\end{array}$ \\
\hline Polity Index & $\begin{array}{c}-0.0908 * * * \\
(0.0335)\end{array}$ & $\begin{array}{c}-0.0822 * * \\
(0.0353)\end{array}$ \\
\hline Financial Reform Composite $_{t}$ & $\begin{array}{l}0.0534 * \\
(0.0309)\end{array}$ & $\begin{array}{c}0.0730 * * \\
(0.0353)\end{array}$ \\
\hline Financial Reform Composite $_{t-1}$ & & $\begin{array}{c}-0.0720 * \\
(0.0372)\end{array}$ \\
\hline Constant & $\begin{array}{c}-26.89 * * * \\
(9.873)\end{array}$ & $\begin{array}{c}-42.62 * * * \\
(13.58)\end{array}$ \\
\hline Number of Observations & 278 & 278 \\
\hline Number of Countries & 84 & 84 \\
\hline F-Stat & 111.3 & 101.5 \\
\hline P-Value & 0.000 & 0.000 \\
\hline Arellano-Bond AR(1) Test & 2.054 & 2.753 \\
\hline P-Value & 0.04 & 0.006 \\
\hline Arellano-Bond AR(2) Test & 2.643 & 2.892 \\
\hline P-Value & 0.008 & 0.004 \\
\hline Sargan Test $\left[\chi^{2}(3)\right]$ & 2.520 & 1.127 \\
\hline P-Value & 0.472 & 0.771 \\
\hline Number of Instruments & 13 & 14 \\
\hline
\end{tabular}




\section{Table 3: Exploratory Factor Analysis}

Factor analysis/correlation

Method: principal factors

Rotation: oblique promax (Kaiser off)
Number of observations

Number of Retained Factors

Number of Parameters
278

4

26

$\begin{array}{lccc}\text { Factor } & \text { Variance } & \text { Proportion } & \text { (Rotated factors are correlated) } \\ \text { Freedom } & 2.284 & 0.513 \\ \text { Robust-ness } & 2.079 & 0.467 \\ \text { Factor3 } & 0.473 & 0.106 \\ \text { Factor4 } & 0.046 & 0.010\end{array}$

LR: independent v. saturated:

$\chi^{2}(28)$

P-Value
$1,469.300$

0.000

Rotated factor loadings (pattern matrix) and unique variances

$\begin{array}{lccccc}\text { Variable } & \text { Freedom } & \text { Robustness } & \text { Factor3 } & \text { Factor4 } & \text { Uniqueness } \\ \text { Directed Credit } & 0.966 & 0.131 & 0.088 & 0.007 & 0.042 \\ \text { Credit Controls } & 0.954 & 0.215 & 0.073 & 0.007 & 0.038 \\ \text { Interest Rate Controls } & 0.253 & 0.549 & 0.225 & 0.156 & 0.560 \\ \text { Entry Barriers } & 0.286 & 0.479 & 0.340 & 0.043 & 0.572 \\ \text { Banking Supervision } & 0.284 & 0.594 & 0.305 & -0.089 & 0.466 \\ \text { Privatization } & 0.296 & 0.334 & 0.425 & 0.023 & 0.620 \\ \text { International Capital Controls } & 0.242 & 0.729 & 0.134 & 0.081 & 0.385 \\ \text { Security Markets Policies } & 0.259 & 0.700 & 0.049 & -0.067 & 0.436\end{array}$

Factor rotation matrix

Freedom Robustness Factor3 Factor4

Freedom

$\begin{array}{llll}0.693 & 0.664 & 0.280 & 0.026\end{array}$

Robust-ness

$-0.719$

0.664

0.204

0.025

Factor3

$-0.050$

$-0.345$

0.933

0.086

Factor4

0.004

$-0.004$

$-0.093$

0.996 
Table 4: Difference GMM Results (Dependent Variable: Remittances as a percentage of GDP)

\begin{tabular}{|c|c|c|}
\hline & $(1)$ & $(2)$ \\
\hline Remittances $_{t-1}(\%$ of GDP) & $\begin{array}{c}-0.0485 \\
(0.153)\end{array}$ & $\begin{array}{c}-0.0974 \\
(0.160)\end{array}$ \\
\hline Emigration Rate $_{t-1}$ (\% of Pop.) & $\begin{array}{c}59.06 * * * \\
(11.09)\end{array}$ & $\begin{array}{c}63.31 * * * \\
(11.79)\end{array}$ \\
\hline $\ln (\text { GDP per Capita })_{t-1}(\$ U S 2000)$ & $\begin{array}{c}3.416^{* * *} \\
(1.184)\end{array}$ & $\begin{array}{c}5.842 * * * \\
(1.811)\end{array}$ \\
\hline Gov. Expenditure $_{t}(\%$ of GDP $)$ & $\begin{array}{l}-0.0129 \\
(0.0914)\end{array}$ & $\begin{array}{l}-0.0248 \\
(0.0975)\end{array}$ \\
\hline Gov. Expenditure $_{t-1}(\%$ of GDP) & $\begin{array}{l}-0.135 * \\
(0.0784)\end{array}$ & $\begin{array}{l}-0.138 * \\
(0.0836)\end{array}$ \\
\hline Inflation $_{t}$ (Consumption) & $\begin{array}{c}0.146 \\
(1.375)\end{array}$ & $\begin{array}{c}-0.0814 \\
(1.485)\end{array}$ \\
\hline Inflation $_{t-1}$ (Consumption) & $\begin{array}{l}-0.707 \\
(0.830)\end{array}$ & $\begin{array}{l}-0.937 \\
(0.899)\end{array}$ \\
\hline Polity Index & $\begin{array}{c}-0.0868 * * * \\
(0.0334)\end{array}$ & $\begin{array}{c}-0.0833 * * * \\
(0.0359)\end{array}$ \\
\hline Freedom Factor ${ }_{t}$ & $\begin{array}{c}0.264 * * \\
(0.131)\end{array}$ & $\begin{array}{c}0.413 * * * \\
(0.155)\end{array}$ \\
\hline Freedom Factort-1 & & $\begin{array}{l}-0.168 \\
(0.149)\end{array}$ \\
\hline Robustness Factor $_{t}$ & $\begin{array}{c}0.199 \\
(0.217)\end{array}$ & $\begin{array}{c}0.259 \\
(0.238)\end{array}$ \\
\hline Robustness Factor $_{t-1}$ & & $\begin{array}{c}-0.583 * * \\
(0.269)\end{array}$ \\
\hline Constant & $\begin{array}{c}-27.11 * * * \\
(10.35)\end{array}$ & $\begin{array}{c}-47.77 * * * * \\
(15.67)\end{array}$ \\
\hline Number of Observations & 278 & 278 \\
\hline Number of Countries & 84 & 84 \\
\hline F-Stat & 111.3 & 99.54 \\
\hline P-Value & 0.000 & 0.000 \\
\hline Arellano-Bond AR(1) Test & 1.978 & 2.656 \\
\hline P-Value & 0.048 & 0.008 \\
\hline Arellano-Bond AR(2) Test & 2.461 & 2.773 \\
\hline P-Value & 0.014 & 0.006 \\
\hline Sargan Test & 2.468 & 0.829 \\
\hline P-Value & 0.481 & 0.842 \\
\hline Number of Instruments & 14 & 16 \\
\hline
\end{tabular}


Figure 1: Impulse Response Functions: Cumulative Effect of a Permanent Change in Financial Reform Composite in Period $t=0$ (Abiad, et al. 2010)

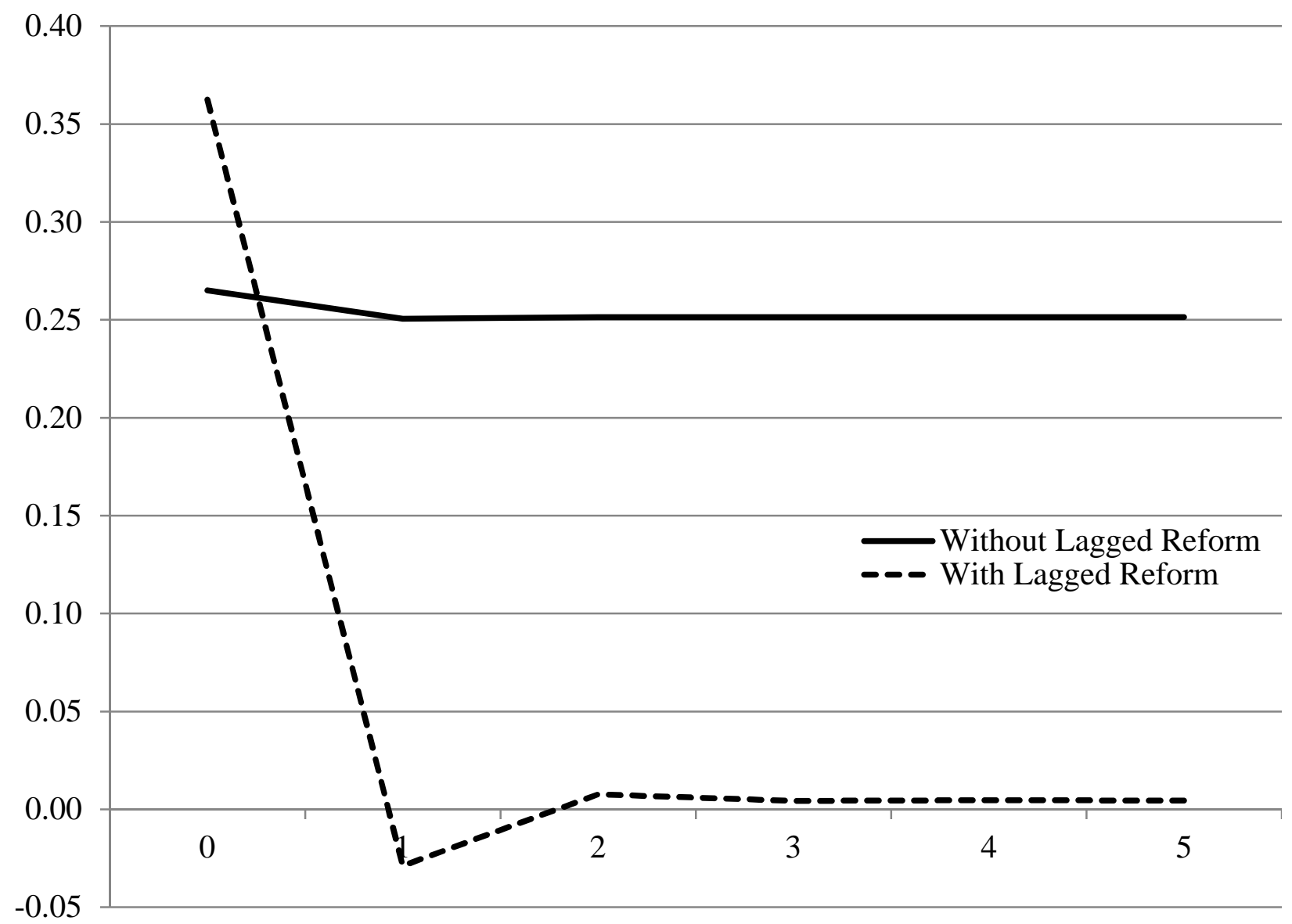


Figure 2: Impulse Response Functions: Cumulative Effect of a Permanent Change in Financial Freedom Factor in Period $t=0$ (Mitra et al. 2010)

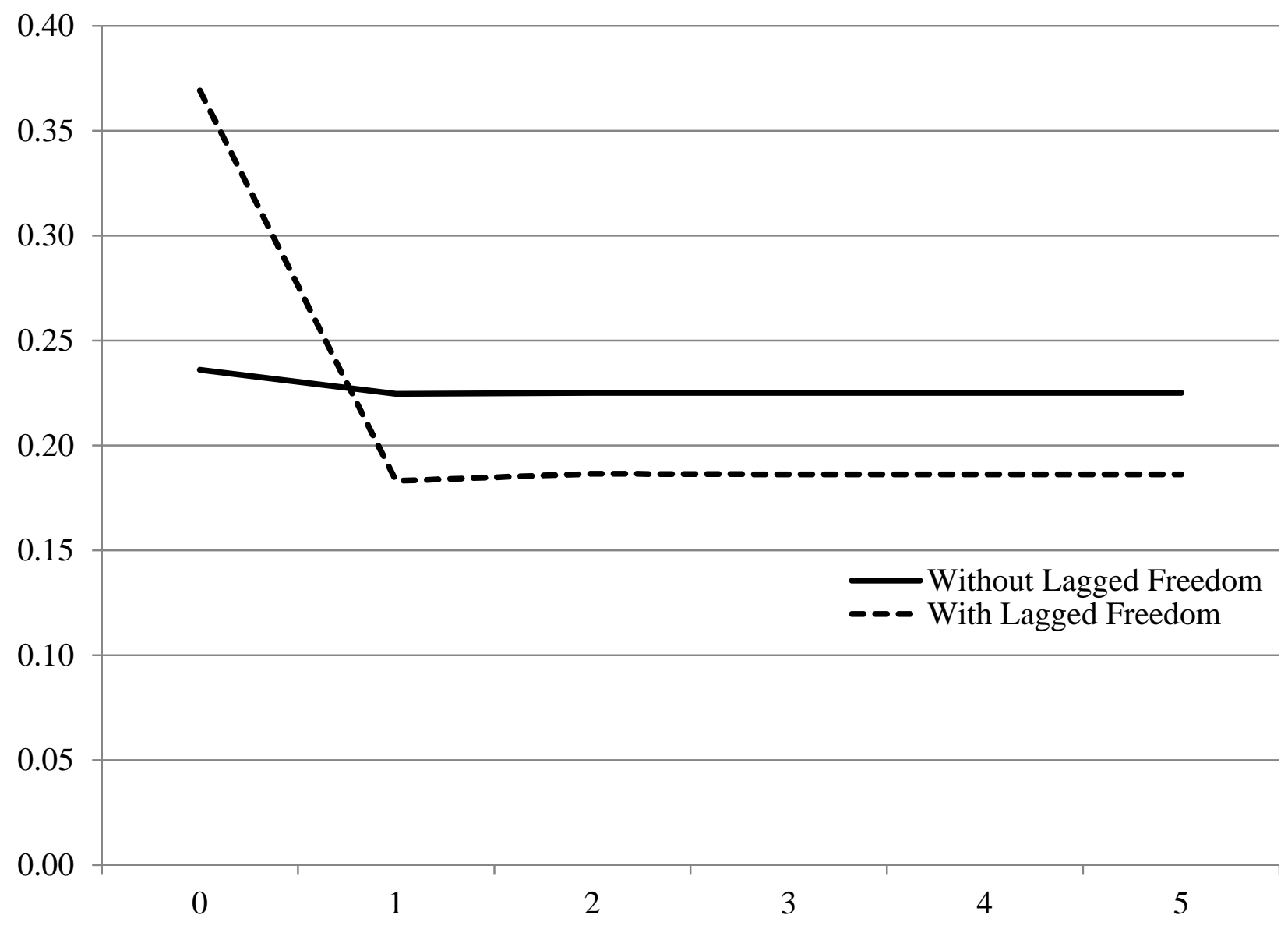


Figure 3: Impulse Response Functions: Cumulative Effect of a Permanent Change in Financial Robustness Factor in Period $t=0$ (Mitra, et al. 2013)

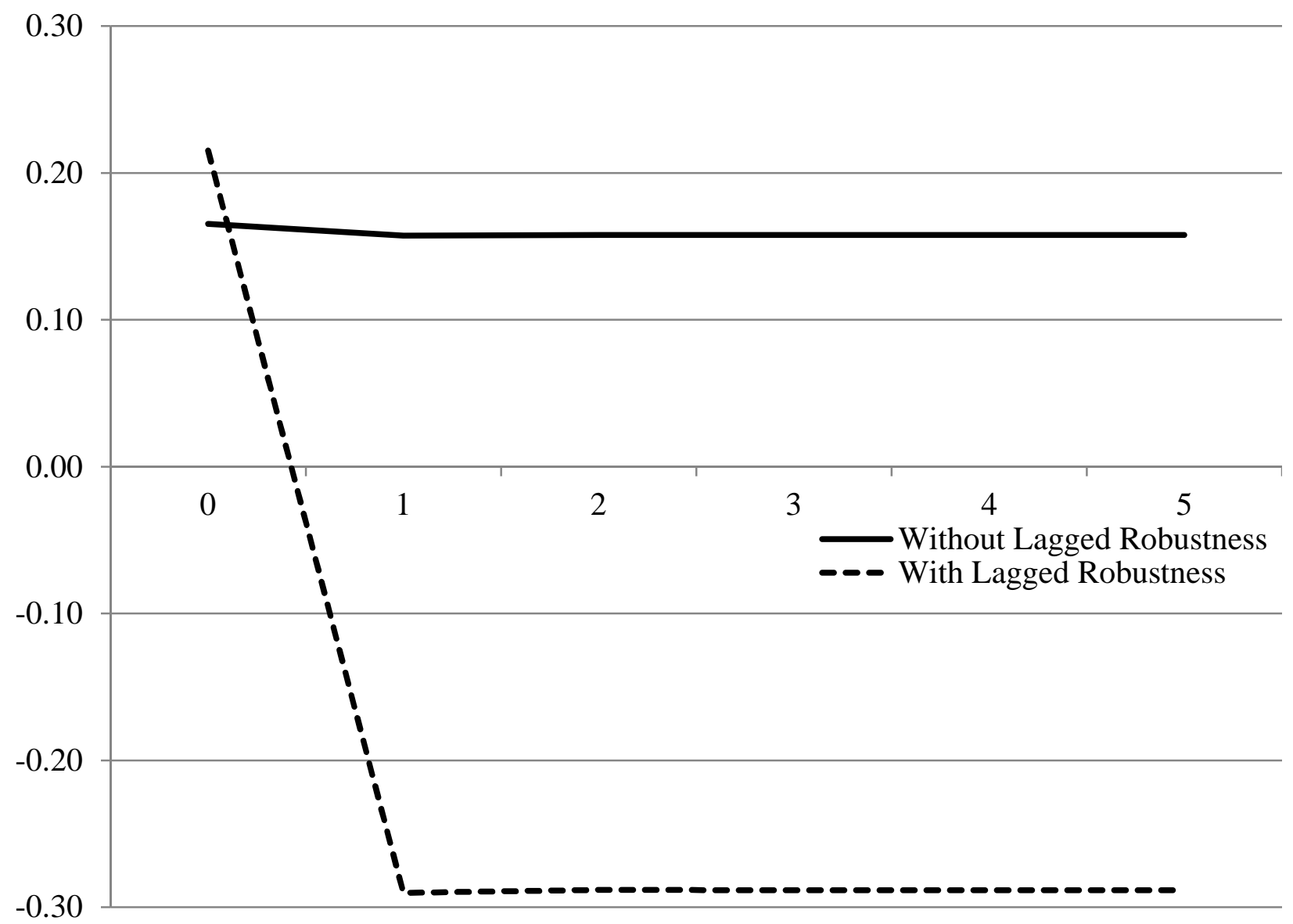


Figure 4: Impulse Response Functions: Cumulative Effect of a Permanent Combined Change in Financial Freedom and Robustness Factors in Period $t=0$ (Mitra, et al. 2013)

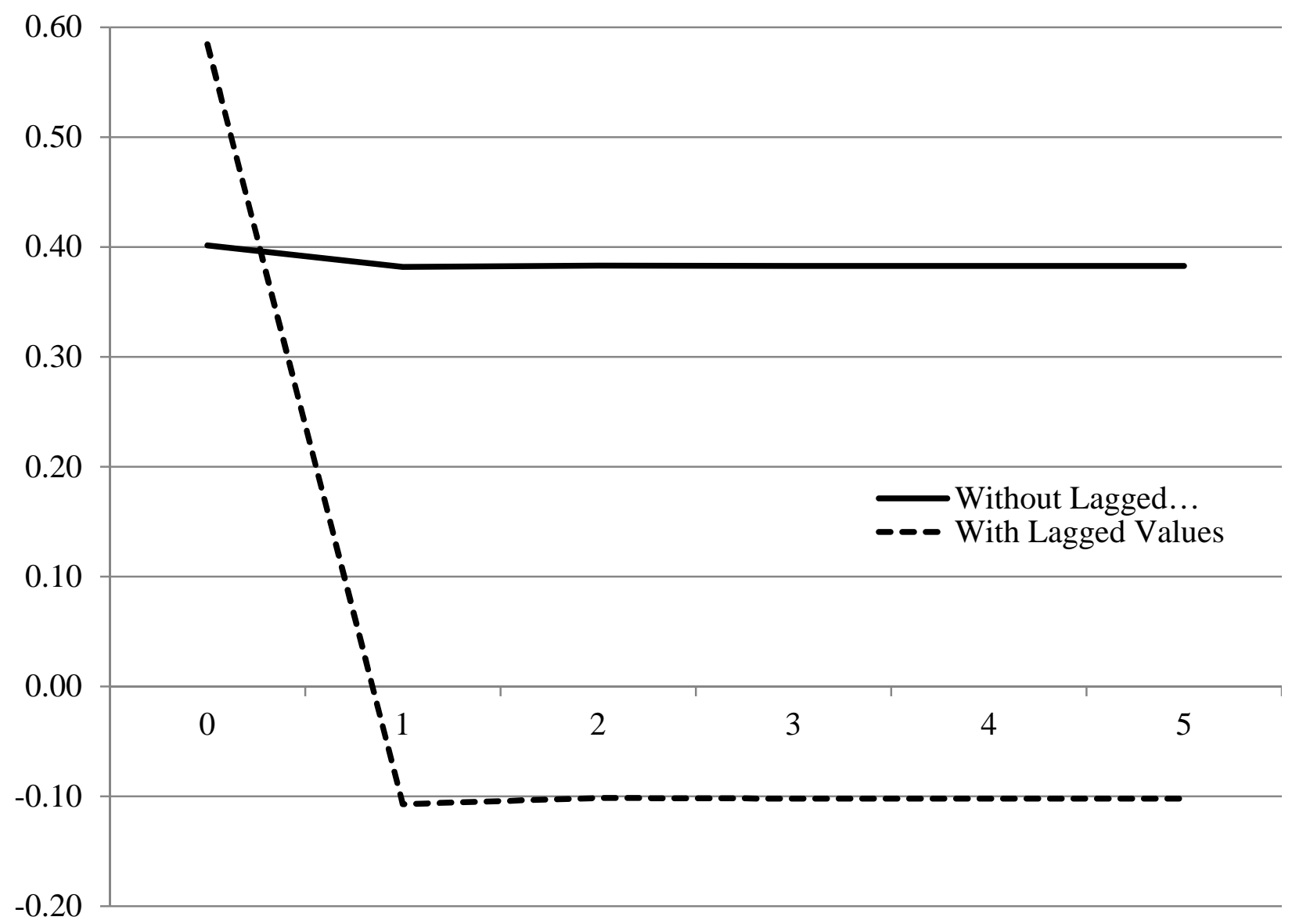




\section{Appendix Table A1: Balanced Panel Difference GMM Results (Dependent Variable: Remittances as a percentage of GDP)}

\begin{tabular}{|c|c|c|c|c|}
\hline & $(1)$ & $(2)$ & (3) & $(4)$ \\
\hline Remittances $_{t-1}(\%$ of GDP) & $\begin{array}{l}-0.113 \\
(0.172)\end{array}$ & $\begin{array}{l}-0.207 \\
(0.182)\end{array}$ & $\begin{array}{l}-0.102 \\
(0.171)\end{array}$ & $\begin{array}{l}-0.203 \\
(0.183)\end{array}$ \\
\hline Emigration Rate $_{t-1}$ (\% of Pop.) & $\begin{array}{c}79.62 * * * \\
(13.47)\end{array}$ & $\begin{array}{c}88.87 * * * \\
(14.51)\end{array}$ & $\begin{array}{c}80.12 * * * \\
(13.49)\end{array}$ & $\begin{array}{c}89.15 * * * \\
(14.56)\end{array}$ \\
\hline $\ln (\text { GDP per Capita })_{t-1}(\$ U S 2000)$ & $\begin{array}{c}2.291 * * \\
(1.157)\end{array}$ & $\begin{array}{c}4.680 * * * \\
(1.673)\end{array}$ & $\begin{array}{c}2.534^{* *} \\
(1.240)\end{array}$ & $\begin{array}{c}5.276 * * * \\
(1.924)\end{array}$ \\
\hline Gov. Expenditure $_{t}(\%$ of GDP $)$ & $\begin{array}{c}0.000130 \\
(0.103)\end{array}$ & $\begin{array}{c}0.00852 \\
(0.111)\end{array}$ & $\begin{array}{c}0.00470 \\
(0.103)\end{array}$ & $\begin{array}{c}0.00124 \\
(0.111)\end{array}$ \\
\hline Gov. Expenditure $_{t-1}$ ( $\%$ of GDP) & $\begin{array}{c}-0.101 \\
(0.0817)\end{array}$ & $\begin{array}{c}-0.129 \\
(0.0881)\end{array}$ & $\begin{array}{l}-0.0879 \\
(0.0827)\end{array}$ & $\begin{array}{l}-0.0956 \\
(0.0905)\end{array}$ \\
\hline Inflation $_{t}$ (Consumption) & $\begin{array}{c}0.281 \\
(1.463)\end{array}$ & $\begin{array}{l}-0.141 \\
(1.597)\end{array}$ & $\begin{array}{c}0.367 \\
(1.461)\end{array}$ & $\begin{array}{l}0.0546 \\
(1.611)\end{array}$ \\
\hline Inflation $_{t-1}$ (Consumption) & $\begin{array}{c}-0.108 \\
(1.217)\end{array}$ & $\begin{array}{c}-0.578 \\
(1.334)\end{array}$ & $\begin{array}{l}-0.0551 \\
(1.225)\end{array}$ & $\begin{array}{c}-0.554 \\
(1.357)\end{array}$ \\
\hline Polity Index & $\begin{array}{l}-0.0219 \\
(0.0332)\end{array}$ & $\begin{array}{c}-0.00984 \\
(0.0357)\end{array}$ & $\begin{array}{l}-0.0142 \\
(0.0332)\end{array}$ & $\begin{array}{r}-0.00476 \\
(0.0363)\end{array}$ \\
\hline Financial Reform Composite $_{t}$ & $\begin{array}{c}0.0272 \\
(0.0314)\end{array}$ & $\begin{array}{c}0.0494 \\
(0.0368)\end{array}$ & & \\
\hline Financial Reform Composite $_{t-1}$ & & $\begin{array}{c}-0.0880 * * \\
(0.0387)\end{array}$ & & \\
\hline Freedom Factor $_{t}$ & & & $\begin{array}{c}0.206 \\
(0.126)\end{array}$ & $\begin{array}{c}0.363^{* *} \\
(0.155)\end{array}$ \\
\hline Freedom Factor $_{t-1}$ & & & & $\begin{array}{c}-0.250 * \\
(0.151)\end{array}$ \\
\hline Robustness Factor ${ }_{t}$ & & & $\begin{array}{l}-0.0226 \\
(0.238)\end{array}$ & $\begin{array}{l}0.0268 \\
(0.262)\end{array}$ \\
\hline Robustness Factor $_{t-1}$ & & & & $\begin{array}{c}-0.620 * * \\
(0.279)\end{array}$ \\
\hline Constant & $\begin{array}{c}-18.88 * \\
(9.804)\end{array}$ & $\begin{array}{c}-38.59 * * * \\
(14.07)\end{array}$ & $\begin{array}{l}-20.89 * \\
(10.75)\end{array}$ & $\begin{array}{c}-44.36 * * * \\
(16.58)\end{array}$ \\
\hline Number of Observations & 224 & 224 & 224 & 224 \\
\hline Number of Countries & 56 & 56 & 56 & 56 \\
\hline F-Stat & 138.9 & 120.1 & 141.2 & 119.7 \\
\hline Arellano-Bond AR(1) Test & 1.623 & 2.582 & 1.554 & 2.467 \\
\hline P-Value & 0.105 & 0.010 & 0.120 & 0.0136 \\
\hline Arellano-Bond AR(2) Test & 2.375 & 2.634 & 2.065 & 2.368 \\
\hline P-Value & 0.018 & 0.008 & 0.039 & 0.0179 \\
\hline Sargan Test $\left[\chi^{2}(3)\right]$ & 3.609 & 2.712 & 3.318 & 2.169 \\
\hline P-Value & 0.307 & 0.438 & 0.345 & 0.538 \\
\hline Number of Instruments & 13 & 14 & 14 & 16 \\
\hline
\end{tabular}

Standard errors in parentheses; $* * * \mathrm{p}<0.01, * * \mathrm{p}<0.05, * \mathrm{p}<0.1$ 